\title{
Extremely low oxygen partial pressures for the storage of 'Royal Gala' apple
}

\author{
Magno Roberto Pasquetti Berghetti* (D), Auri Brackmann (D), Fabio Rodrigo Thewes (D), \\ Erani Eliseu Schultz (D), Vagner Ludwig (D), Lucas Mallmann Wendt (D), Flavio Roberto Thewes (D), \\ Suele Fernanda Prediger Schmidt (iD \\ Universidade Federal de Santa Maria - Departamento de Fitotecnia - Santa Maria (RS), Brazil.
}

\begin{abstract}
The aim of this study was to evaluate the effect of storing 'Royal Gala' apple under extremely low oxygen partial pressures on their anaerobic metabolism, ethylene production and fruit quality after 9 months of storage plus 7 days of shelf life at $20^{\circ} \mathrm{C}$. The storage conditions tested were: $1.2 \mathrm{kPaO}_{2}+2.0 \mathrm{kPa} \mathrm{CO} ; 0.7 \mathrm{kPaO}_{2}+1.5 \mathrm{kPa} \mathrm{CO} ; 0.5 \mathrm{kPaO}_{2}+1.2 \mathrm{kPa} \mathrm{CO}_{2} ; 0.4 \mathrm{kPa} \mathrm{O}_{2}+$ $1.2 \mathrm{kPaCO}_{2}$ and $0.25 \mathrm{kPaO}_{2}+0.0 \mathrm{kPaCO}_{2}$. The fruit storage temperature was $1.0^{\circ} \mathrm{C}( \pm 0.1)$. Fruit stored at $0.4 \mathrm{kPaO}_{2}+1.2 \mathrm{kPaCO}_{2}$ maintained higher flesh firmness and a higher percentage of healthy fruit. The fruit stored under the $0.25 \mathrm{kPaO}_{2}+0.0 \mathrm{kPa} \mathrm{CO}$ condition had lower flesh firmness as well as a reduced percentage of healthy fruit and a high production of anaerobic metabolism compounds, such as ethanol and ethyl acetate, which may have caused fruit quality loss. The storage of 'Royal Gala' apple under $0.4 \mathrm{kPaO}_{2}+1.2 \mathrm{kPa} \mathrm{CO}_{2}$ is a technique that can be commercially applied to keep a better fruit quality after a 9 months storage period.
\end{abstract}

Key words: anaerobic metabolism, ethyl acetate, ethylene, Malus domestica, physiological disorders.
Received:

Nov 27, 2018

Accepted:

Nov 28, 2019

Section Editor:

Daniel Alexandre Neuwald

${ }^{\star}$ Correspondence author: magno.pasquetti@gmail.com

\section{INTRODUCTION}

Brazil has a production of about 1.1 million tons of apples, mainly concentrated in the states of Rio Grande do Sul and Santa Catarina, where Rio Grande do Sul produced 490,000 tons in the 2017 harvest (Agapomi 2018). Amongst the main cultivars is the 'Royal Gala', discovered in New Zealand in 1971, from a mutation of the cultivar Gala (Camilo and Denardi 2006). This cultivar has the potential to meet the requirements of Brazilian consumers because it presents a uniform red coloration of the epidermis and sweet taste, which gives it a good value and commercial acceptance (Brackmann et al. 2012).

Since the production of apples is concentrated in a short period of the year, the use of appropriate storage techniques is very important, so the fruit can be supplied throughout the entire year (Brackmann et al. 2008). A widely used storage technique is the controlled atmosphere (CA), a method that consists of reducing oxygen $\left(\mathrm{O}_{2}\right)$ partial pressure and raising carbon dioxide $\left(\mathrm{CO}_{2}\right)$ in the storage chamber, thereby reducing fruit metabolism and extending the shelf life of the apple (Brackmann et al. 2013; Ceretta et al. 2010). However, several losses due to decay incidence and flesh breakdown occur in CA storage (Watkins 2006; Watkins 2008). The partial pressure of $\mathrm{O}_{2}$ used during the storage is one of the most important factors in the CA storage. The reduction of $\mathrm{O}_{2}$ to partial pressure that is too low (below $0.3 \mathrm{kPaO}_{2}$ ), may increase the production of volatile compounds such as alcohol, acetaldehyde and ethyl acetate, which in high concentrations can be harmful to the fruit, reducing the flesh firmness and increasing the occurrence of physiological disorders (Both et al. 2017).

The metabolic pathways of the anaerobic metabolism begin with glycolysis, which converts glucose into pyruvate, which is further converted into acetaldehyde, ethanol and ethyl acetate releasing $\mathrm{CO}^{2}$ in this process (Yang and 
Hoffman 1984), which is activated when there is an insufficient $\mathrm{O}_{2}$ supply, which is the final acceptor of the electron transport chain (Zabalza et al. 2009).

One of the techniques additional to CA, in order to maintain higher quality of the fruit, is the extremely low oxygen (ELO) storage. This technique consists of storing the fruit at oxygen partial pressures above the anaerobic compensation point but lower than in CA, which reduces the metabolism and consequently the consumption of sugars and acids by cell respiration (Weber et al. 2013). The storage of apple under extremely low oxygen (ELO) partial pressures, when carried dynamically out, for example in dynamic controlled atmosphere monitored by chlorophyll fluorescence (DCA-CF), maintains higher quality of fruit when they are stored in a $0.4 \mathrm{kPa}$ oxygen partial pressure in comparison to the conventional $\mathrm{CA}\left(1.0 \mathrm{kPa} \mathrm{O}_{2}\right.$ $+1.2 \mathrm{kPa} \mathrm{CO}_{2}$ ) (Zanella et al. 2008; Weber et al. 2016). However, it is likely that extremely low partial pressures of oxygen (below $0.5 \mathrm{kPa}_{2}$ ) used in a static atmosphere may have a good effect on apple quality maintenance.

The aim of this study was to evaluate the effect of storing 'Royal Gala' apple at extremely low oxygen partial pressures on the anaerobic metabolism, ethylene production and fruit quality after 9 months of storage followed by 7 days of shelf life at $20^{\circ} \mathrm{C}$.

\section{MATERIAL E METHODS}

'Royal Gala' apples, harvested in a commercial orchard located in Vacaria (RS - Brazil), were used in this trial. The selection of fruits, such as discard of small fruits, with defects or with mechanical lesions, for the composition of the experimental samples was performed after the fruits were harvested and transported to the Postharvest Research Center of the Federal University of Santa Maria.

The samples were then homogenized by size and each composed of 30 fruits. The experiment was conducted in a completely randomized design, containing five treatments with four replicates each. Three fruit samples were submitted to the initial analysis, presenting the following values for each parameter evaluated: soluble solids (SS) of 11.6\%; flesh firmness of $83.8 \mathrm{~N}$; respiration rate of $15.1 \mathrm{mg} \mathrm{CO}_{2} \mathrm{~kg}^{-1} \cdot \mathrm{h}^{-1} ; 6.1$ of iodine-starch index. Evaluated using the method proposed by Streif (1984), with an index of 1 (all fruit with starch) to 10 (without starch); activity of the ACC oxidase enzyme of $30.5 \mathrm{\eta g}$ $\mathrm{C}_{2} \mathrm{H}_{4} \mathrm{~kg}^{-1} \cdot \mathrm{h}^{-1}$; titratable acidity of $4.8 \mathrm{meq} 100 \mathrm{~m} \cdot \mathrm{L}^{-1}$ and ethylene production of $43.7 \mu \mathrm{g} \cdot \mathrm{kg}^{-1} \cdot \mathrm{h}^{-1}$. The following storage conditions were evaluated: $\mathrm{CA}$ at $1.0 \mathrm{kPaO}_{2}+2.0 \mathrm{kPa} \mathrm{CO}_{2}$ (conventional CA), $\mathrm{ULO}$ at $0.7 \mathrm{kPa} \mathrm{O}_{2}+1.5 \mathrm{kPa} \mathrm{CO}_{2}$ and ULO at $0.5 \mathrm{kPaO}_{2}+1.2 \mathrm{kPa} \mathrm{CO}_{2}$ and $\mathrm{ELO}$ at $0.4 \mathrm{kPaO}_{2}+1.2 \mathrm{kPaCO}_{2}$ and ELO at $0.25 \mathrm{kPa} \mathrm{O}_{2}+0.0 \mathrm{kPa} \mathrm{CO}_{2}$. The fruits were stored in $230 \mathrm{~L} \mathrm{CA}$ rooms that were hermetically sealed and the respective treatments were established.

The fruit storage temperature was set at $1.0^{\circ} \mathrm{C}( \pm 0.1)$ and relative humidity at $94 \%( \pm 2.0)$. The maintenance of moisture during storage was obtained with the aid of containers with calcium chloride that were placed inside the chamber (10 g.kg-1 fruit), which absorbed excess moisture in the room.

Electronic thermostats were used for the daily monitoring of the temperature, along with a mercury thermometer that was inserted in the fruits kept in the cold room. After placing the fruits in the experimental CA rooms, the temperature was reduced to $5.0^{\circ} \mathrm{C}$ on the first day and then it was daily reduced in $1.0^{\circ} \mathrm{C}$ until the final storage temperature.

The atmospheres were installed after the fruits reached $1.0^{\circ} \mathrm{C}$. The oxygen partial pressures were obtained by flushing the CA rooms with nitrogen. The oxygen was reduced by the $\mathrm{N}_{2}$ flushing gradually on the first day to $5.0 \mathrm{kPa}$. Thereafter, during the first storage week, the oxygen was reduced down to $1.0 \mathrm{kPa}$ in all the storage conditions. Subsequently, the pre-established partial pressure for each oxygen storage condition was reduced by the fruits' respiration. The $\mathrm{CO}_{2}$ partial pressure was obtained by the fruit respiration. A gas analyzer (ULTRAMAT-23, Siemens) was used to measure the gas partial pressures during the storage period. A gas control device with a software brand Valis (Lajeado, Rio Grande do Sul) was automatically programmed to make four daily readings of $\mathrm{O}_{2}$ and $\mathrm{CO}_{2}$, comparing the reading to the preset partial pressure (set point) of each treatment. If the $\mathrm{CO}_{2}$ partial pressures were above the established set point, the excess was absorbed by an absorber with $\mathrm{Ca}(\mathrm{OH})_{2}$ and if the $\mathrm{O}_{2}$ partial pressure was below the expected, cold air was injected into the chamber. 
After 9 months of storage, the fruits were removed from storage and kept at $20^{\circ} \mathrm{C}$, for shelf life, for 7 days. After this period the following parameters were evaluated:

a. flesh firmness: part of the epidermis was removed from the equatorial regions of the fruits, and with the aid of a manual penetrometer (Effegi) with a $11 \mathrm{~mm}$ tip, the force required to insert in the fruit flesh was measured. The results were expressed in Newton $(\mathrm{N})$;

b. titratable acidity: was evaluated by titration with $\mathrm{NaOH} 0.1 \mathrm{~mol} \cdot \mathrm{L}^{-1}$, of $10 \mathrm{~mL}$ of diluted juice in $100 \mathrm{~mL}$ of distilled water until $8.1 \mathrm{pH}$. The results of the determination were expressed in meq $100 \mathrm{mg}^{-1}$;

c. soluble solids (SS): determined with the aid of a refractometer. The juice was obtained with samples of 30 fruits in each replicate and the results were expressed in \%;

d. flesh breakdown: All the 30 fruits of each sample were cut in half and then the presence of browning in the flesh was visually evaluated. The results were expressed in percentage;

e. ethylene production: determined using $1,500 \mathrm{~g}$ of fruit kept hermetically sealed in glass jars with a volume of $5 \mathrm{~L}$. The jars with fruits remained closed for about $1 \mathrm{~h}$, then 2 gas samples were removed from the headspace with $1.0 \mathrm{~mL}$ syringe, which were then injected into a gas chromatograph (Varian, Star 3400 CX, Palo Alto, USA) fitted with a flame ionization detector (FID) and a Porapak N80/100 column, with column, injector and detector temperatures of 90,140 and $240{ }^{\circ} \mathrm{C}$, respectively;

f. ACC oxidase activity: determined according to Bufler (1986). The data were expressed in $\mathrm{ng} \mathrm{C}_{2} \mathrm{H}_{4} \mathrm{~kg}^{-1} \cdot \mathrm{h}^{-1}$;

g. decay incidence and pulp cracking: evaluated by counting fruit that presented any symptoms (lesion higher than $5 \mathrm{~mm}$ ). After opening the chambers and exposing the fruits at $20^{\circ} \mathrm{C}$, the decay incidence was evaluated. The results were expressed as a percentage;

h. mealiness: was determined by quantification of fruits that presented mealy pulp. Data were expressed as a percentage;

i. acetaldehyde, ethanol and ethyl acetate: were determined according to Saquet and Streif (2008); a seedless flesh sample was excised from the equatorial region of the fruit with the aid of a Philips Walita centrifuge. After that, $10 \mathrm{~mL}$ juice was placed in a $20 \mathrm{~mL}$ sealed vial. The juice samples were warmed in a water bath at $70{ }^{\circ} \mathrm{C}$ and kept during $30 \mathrm{~min}$. Afterwards, a $100 \mu \mathrm{L}$ sample of the headspace was injected into a Dani gas chromatograph fitted with a capillary DN-WAX column. The temperatures of the injector and detector were 60 and $250{ }^{\circ} \mathrm{C}$, respectively. The results were expressed in $\mu \mathrm{L} \cdot \mathrm{L}^{-1}$;

j. using the methodology of Mannapperuma et al. (1991), the internal ethylene concentration was determined using the methodology of Mannapperuma et al. (1991), in which two $1.0 \mathrm{~mL}$ samples of this air were collected and injected into the same gas chromatograph used for the quantification of ethylene production. The results were expressed in $\mu \mathrm{g} \cdot \mathrm{L}^{-1}$;

k. respiration rate: the same glass jars used for the evaluation of ethylene production was used for this assessment. The $\mathrm{CO}_{2}$ released by the fruits was measured using an Isolcell electronic gas analyzer. The results were expressed in $\mathrm{mg} \mathrm{CO} \cdot \mathrm{kg}^{-1} \cdot \mathrm{h}^{1}$.

The data matrix was scaled for each variable to obtain the same weight for all variables ( mean $=0$ and variance $=1$ ) using the software Unscrambler X (version 9.7, CAMOA / S, Trondheim, Norway). After this, a principal component analysis (PCA) was performed to show an overview of the results. Data and means were subjected to analysis of variance (ANOVA) and the Tukey's test, with $5 \%$ probability of error $(\mathrm{p}<0.05)$, respectively.

\section{RESULTS AND DISCUSSION}

The plant hormone ethylene present in the form of gas is responsible for triggering the ripening process of fruit (Saltveit 1999; Li et al. 2002; Taiz and Zieger 2009). ACC oxidase and ACC synthase are essential enzymes for the ethylene biosynthesis pathway (Yang and Hoffman 1984; Wang et al. 2002). A reduction in the activity of the ACC oxidase enzyme was observed with the decrease of the oxygen partial pressures; the treatments with $0.5,0.4$ and $0.25 \mathrm{kPa}$ of $\mathrm{O}_{2}$ caused the 
lowest activity of the enzyme (Fig. 1c). This reduction can be explained as a consequence of extremely low partial pressures of oxygen, where molecular oxygen becomes limited to the ACC oxidase activity. Moreover, this enzyme is responsible for ethylene synthesis and is activated or inhibited depending on the concentration of the anaerobic metabolism products (Yang and Hoffman, 1984; Beaulieu and Saltveit 1997). A high concentration of acetaldehyde and ethanol can inhibit the activity of the ACC oxidase and reduce the ethylene production by fruit (Beaulieu and Saltveit 1997; Pesis 2005; Asoda et al. 2009; Thewes et al. 2015; Weber et al. 2016; Both et al. 2017), which helps to explain the low ACC oxidase activity in the fruits stored at 0.4 and $0.25 \mathrm{kPaO}_{2}$. There was no significant difference for titratable acidity and soluble solids (Fig. 1a and $b$ ) for the tested conditions, and there were no differences with the decrease of partial pressures of $\mathrm{O}_{2}$. These results are in agreement with the results found by Brackmann et al. (2015).

(a)

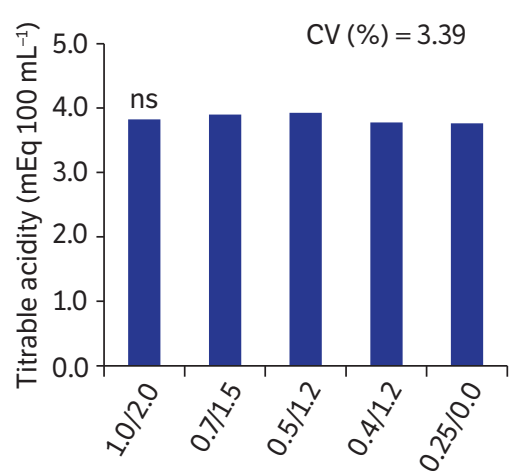

(d)

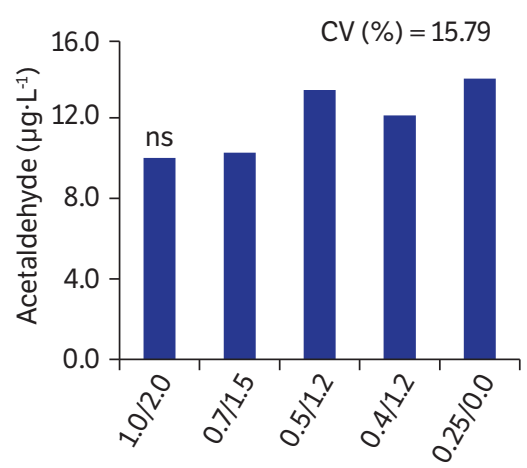

(b)

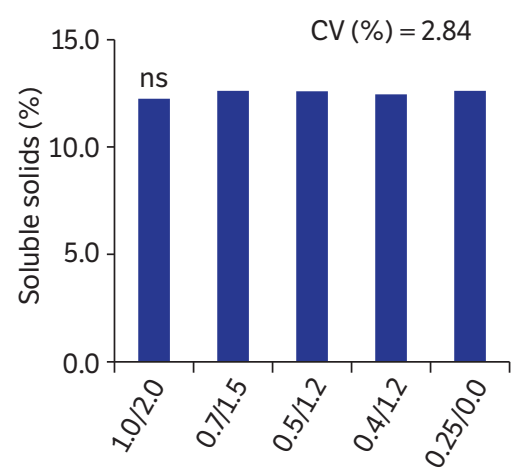

(e)

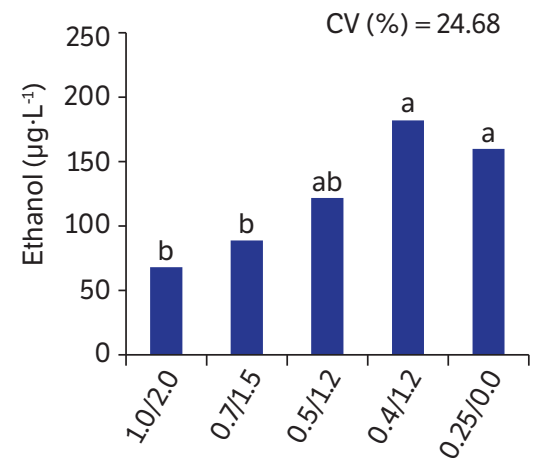

(c)

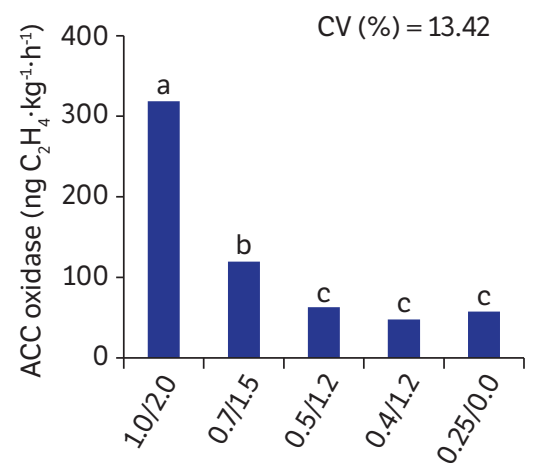

(f)

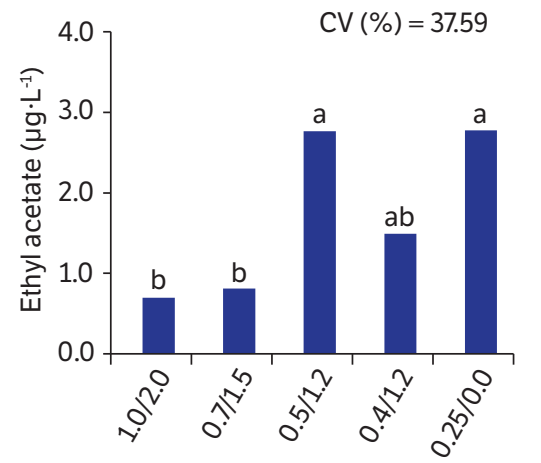

Figure 1. Titratable acidity (a), soluble solids (b), ACC oxidase enzyme activity (c), acetaldehyde (d), ethanol (e) and ethyl acetate (f) of 'Royal Gala' apples stored under ultra-low oxygen partial pressures. Averages followed by equal letter on the same parameter, do not differ by Tukey's test, at $5 \%$ of error probability.

The production and internal ethylene concentration increased significantly at the $7^{\text {th }}$ day of shelf life in comparison at 0 days when apples were stored under CA with $1.0 \mathrm{kPa}$ of $\mathrm{O}_{2}+2.0 \mathrm{kPa}$ of $\mathrm{CO}_{2}$ (Table 1). This finding is associated to a higher activity of the enzyme ACC oxidase measured in these fruits and conditions (Fig. 1c). However, fruits stored at $\mathrm{O}_{2}$ partial pressures of $0.5,0.4$, and $0.25 \mathrm{kPa} \mathrm{O}_{2}$ showed lower ethylene production and internal ethylene concentration (IEC) at chamber opening and after 7 days shelf life at $20^{\circ} \mathrm{C}$ in comparison to the fruits stored under conditions of conventional CA with $1.2 \mathrm{kPa}$ of $\mathrm{O}_{2}$. This result is associated to the lower activity of the ACC oxidase measured under low oxygen (Fig. 1c).

The internal $\mathrm{CO}_{2}$ concentration may be related to several factors, such as maturity stage, pulp structure, respiration rate and physiological disorders. According to Castro et al. (2008), high partial pressures of $\mathrm{CO}_{2}$ inside the apple can cause oxidative stress and the production of free radicals leading to membrane change. The fruits stored at $0.7 \mathrm{kPaO}_{2}+1.5 \mathrm{kPaCO}_{2}$ 
presented higher internal $\mathrm{CO}_{2}$ concentration immediately after being removed from the rooms (Table 1). This result may have occurred due to the combined effect of the ULO condition, which induced the anaerobic metabolism pathway, and high $\mathrm{CO}_{2}$ partial pressure, which differs from the other conditions with lower oxygen partial pressures. Furthermore, the fruits submitted to this treatment presented a higher respiration rate at chamber opening (Table 1), which may have favored the accumulation of $\mathrm{CO}_{2}$ in the fruits. The lowest internal $\mathrm{CO}_{2}$ concentration, in comparison to oxygen conditions lower than $1.0 \mathrm{kPa}$, was observed in the fruits stored with $0.25 \mathrm{kPaO}_{2}+0.0 \mathrm{kPa} \mathrm{CO}_{2}$. The lower accumulation of $\mathrm{CO}_{2}$ in fruits stored under $0.0 \mathrm{kPa} \mathrm{CO}$ may be related to the higher accumulation of fermentation products, which influenced the decrease in

Table 1. Internal ethylene concentration (IEC), ethylene production, internal carbon dioxide concentration (ICO ${ }_{2}$ ) and respiration rate of 'Royal Gala' apples stored under extremely low oxygen partial pressures.

\begin{tabular}{|c|c|c|c|c|c|c|}
\hline \multirow{3}{*}{$\begin{array}{l}\text { Conditions } \\
\left(\mathrm{O}_{2} / \mathrm{CO}_{2}\right)\end{array}$} & \multirow{2}{*}{\multicolumn{2}{|c|}{$\begin{array}{c}\text { IEC } \\
\left(\mu \mathrm{g} \cdot \mathrm{L}^{-1}\right)\end{array}$}} & \multirow{3}{*}{ Mean } & \multirow{2}{*}{\multicolumn{2}{|c|}{$\begin{array}{l}\text { Ethylene production } \\
\left(\mu \mathrm{g} \mathrm{C} \mathrm{C}_{4} \cdot \mathrm{kg}^{-1} \cdot \mathrm{h}^{-1}\right) \\
\text { Shelf life at } 20^{\circ} \mathrm{C}\end{array}$}} & \multirow{3}{*}{ Mean } \\
\hline & & & & & & \\
\hline & 0 days & 7 days & & 0 days & 7 days & \\
\hline $1.0 / 2.0$ & $6.32 \mathrm{abB}^{\star}$ & $46.25 \mathrm{aA}$ & 26.28 & $3.33 \mathrm{aB}$ & $31.66 \mathrm{aA}$ & 17.50 \\
\hline $0.7 / 1.5$ & $6.88 \mathrm{aA}$ & $0.66 \mathrm{bB}$ & 3.75 & $1.50 \mathrm{aB}$ & $8.46 \mathrm{bA}$ & 4.98 \\
\hline $0.5 / 1.2$ & $1.36 \mathrm{bcA}$ & $0.20 \mathrm{bA}$ & 0.78 & $0.57 \mathrm{aA}$ & $1.22 \mathrm{cA}$ & 0.90 \\
\hline $0.4 / 1.2$ & $1.27 \mathrm{bcA}$ & $0.18 \mathrm{bA}$ & 0.73 & $0.27 a A$ & $0.86 \mathrm{cA}$ & 0.56 \\
\hline $0.25 / 0.0$ & $0.46 c A$ & $0.08 \mathrm{bA}$ & 0.27 & $0.37 a A$ & $0.85 c A$ & 0.61 \\
\hline Mean & 3.26 & 9.47 & 6.37 & 1.21 & 8.61 & 4.91 \\
\hline \multirow[t]{2}{*}{ CV (\%) } & \multicolumn{2}{|c|}{41.57} & \multicolumn{4}{|c|}{30.80} \\
\hline & \multicolumn{2}{|c|}{$\begin{array}{c}\mathrm{ICO}_{2} \\
\left(\mathrm{mg} \cdot 100 \mathrm{~mL}^{-1}\right)\end{array}$} & \multicolumn{4}{|c|}{$\begin{array}{l}\text { Respiration rate } \\
\left(\mathrm{mg} \mathrm{CO}_{2} \cdot \mathrm{kg}^{-1} \cdot \mathrm{h}^{-1}\right)\end{array}$} \\
\hline $1.0 / 2.0$ & 4.97bcA & 5.19aA & 5.09 & $11.47 \mathrm{bcA}$ & 12.11aA & 8.82 \\
\hline $0.7 / 1.5$ & 8.01aA & $4.62 \mathrm{aB}$ & 6.32 & $14.94 a \mathrm{~A}$ & $9.66 \mathrm{bB}$ & 9.93 \\
\hline $0.5 / 1.2$ & $5.72 \mathrm{bA}$ & $4.95 \mathrm{aA}$ & 5.34 & 13.27abA & $8.00 \mathrm{bB}$ & 8.67 \\
\hline $0.4 / 1.2$ & $6.03 \mathrm{bA}$ & $4.60 \mathrm{aB}$ & 5.32 & $12.15 \mathrm{bcA}$ & $7.82 \mathrm{bB}$ & 8.07 \\
\hline $0.25 / 0.0$ & $4.07 \mathrm{cA}$ & $4.46 a \mathrm{~A}$ & 4.27 & $10.70 \mathrm{cA}$ & $8.86 \mathrm{bB}$ & 7.61 \\
\hline Mean & 5.76 & 4.77 & 5.27 & 12.50 & 9.29 & 8.62 \\
\hline CV (\%) & \multicolumn{2}{|c|}{11.09} & \multicolumn{4}{|c|}{8.76} \\
\hline
\end{tabular}

*Averages followed by equal letter on the same parameter, lower case in the columns and uppercase in the lines, do not differ by Tukey’s test, at $5 \%$

metabolism, observed by the low respiration rate after being removed from the chamber. After 7 days at $20^{\circ} \mathrm{C}$, there was no difference among the assessed conditions (Table 1).

The $0.5 \mathrm{kPaO}_{2}+1.2 \mathrm{kPaCO}_{2}$ and $0.7 \mathrm{kPa} \mathrm{O}_{2}+1.5 \mathrm{kPaCO}_{2}$ conditions presented higher respiration rates at chamber opening. However, at the $7^{\text {th }}$ day there was a higher respiration rate in the fruits stored at $1.2 \mathrm{kPa} \mathrm{O}_{2}+2.0 \mathrm{kPa} \mathrm{CO}_{2}$ partial pressure (Table 1). This may be associated to the ripening stage of fruit that were stored at higher oxygen partial pressures.

Regarding the acetaldehyde production, no difference was found among the evaluated treatments (Fig. 1d). However, there was a difference verified among the assessed conditions in regard to the ethanol production. The ethanol production increased as the $\mathrm{O}_{2}$ decreased, wherein the fruit stored under the 0.4 and $0.25 \mathrm{kPa}$ partial pressures of $\mathrm{O}_{2}$ demonstrated a higher production of ethanol in comparison to the samples stored under 0.7 and $1.0 \mathrm{kPa}$ of $\mathrm{O}_{2}$ (Fig. 1e). This occurs due to the lack of molecular oxygen to serve as an electron acceptor in the respiratory chain (Lehninger et al. 2002). It may also be related to the increased activity of the alcohol dehydrogenase (ADH) under extremely low partial pressures of $\mathrm{O}_{2}(0.4$ and $0.25 \mathrm{kPa})$. The $\mathrm{ADH}$ enzyme acts on the conversion of acetaldehyde to ethanol using the NADH (nicotinamide adenine dinucleotide reduced) produced in glycolysis (Saquet and Streif 2008; Lee et al. 2012). Nanos et al. (1992) also observed similar results in pears stored under extremely low partial 
pressure of oxygen $(0.25 \mathrm{kPa})$, with high ethanol production and higher $\mathrm{ADH}$ activity, agreeing with the results obtained at the present work.

Fruit storage under partial pressures of $0.25 \mathrm{kPa}$ of $\mathrm{O}_{2}+0.0 \mathrm{kPa}$ of $\mathrm{CO}_{2}$ maintained lower percentage of healthy fruits, flesh firmness, and flesh breakdown compared to the conditions of $0.4 \mathrm{kPa}$ of $\mathrm{O}_{2}+1.2 \mathrm{kPa}$ of $\mathrm{CO}_{2}$ (Fig. 2c, e and f). Probably, the extremely low oxygen condition induced the anaerobic metabolism and formation of compounds such as acetaldehyde, ethanol and ethyl acetate, which are toxic substances, providing physiological disorders (Pedreschi et al. 2009). In agreement with Zanella (2003) and Pedreschi et al. (2009), the present work also observed higher anaerobic metabolism compounds like ethanol and ethyl acetate (Fig. 1e and f), which may directly influence the quality of 'Royal Gala' apples stored. Forney, Kalt and Jordan (2000) also observed higher ethyl acetate production of strawberry stored at CA, which was attributed to an off flavor. On the other hand, Both et al. (2014) did not find any difference between ultralow oxygen partial pressure

(a)

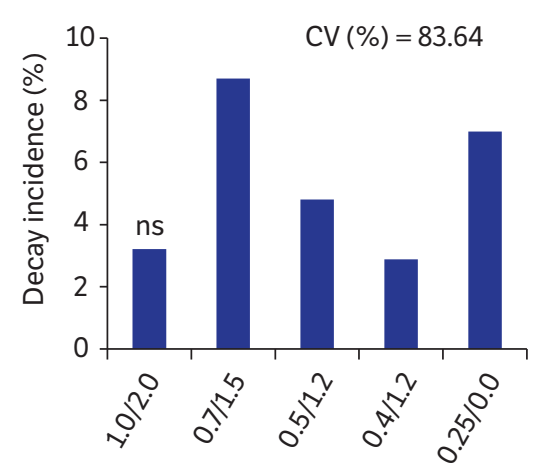

(d)

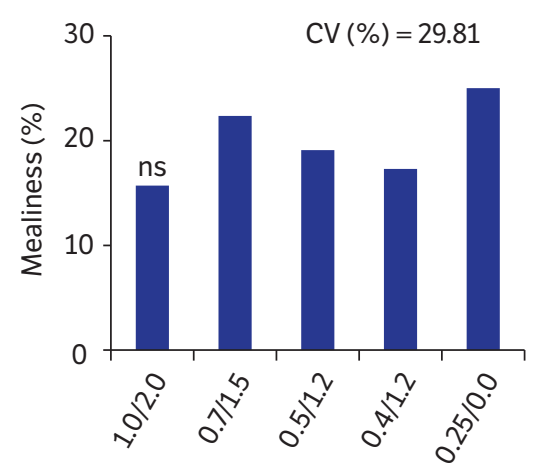

(b)

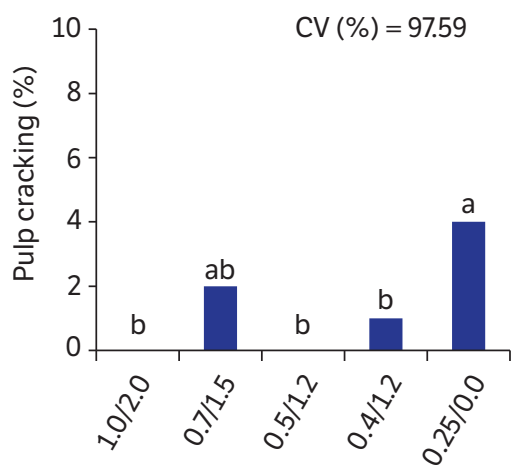

(e)

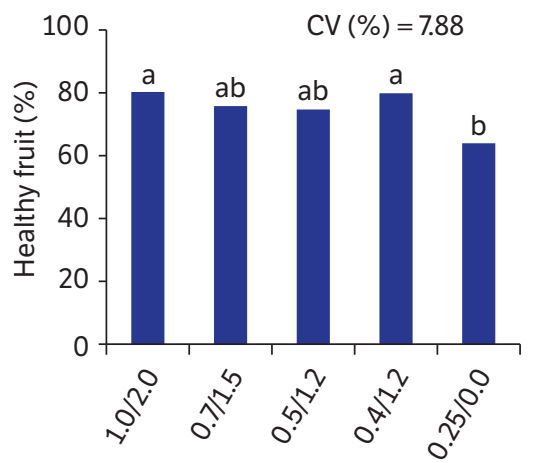

(c)

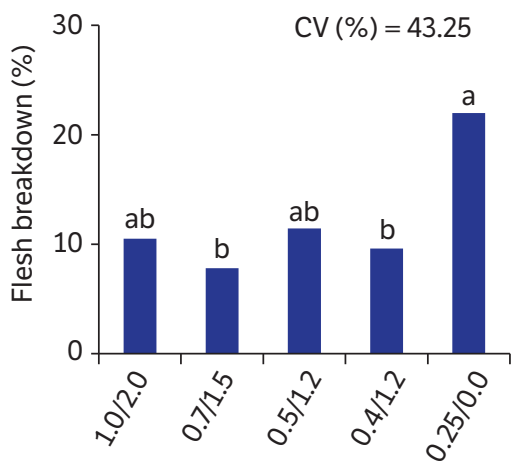

(f)

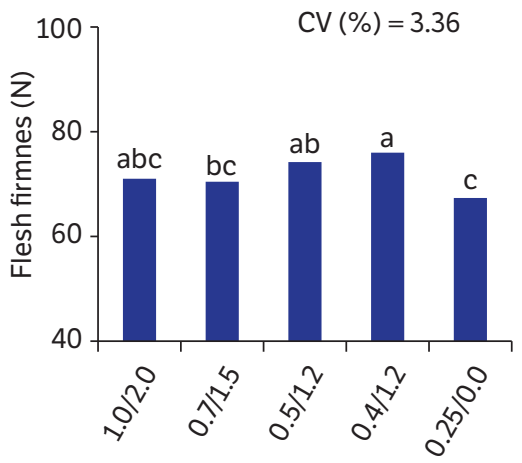

Figure 2. Decay incidence (a), pulp cracking (b), flesh breakdown (c), mealiness (d), healthy fruit (e) and flesh firmness (f) of 'Royal Gala' apples stored under extremely low oxygen partial pressures. Averages followed by equal letter on the same parameter do not differ by Tukey's test, at $5 \%$ of error probability.

(0.5, 0.7 and $0.8 \mathrm{kPa})$ and $\mathrm{CA}\left(1.0 \mathrm{kPa} \mathrm{O}_{2}\right)$ on the anaerobic metabolism compounds concentration after eight months of storage of 'Royal Gala' apples.

The principal component analysis (PCA) (Fig. 3a and b) shows the degree of correlation among the storage conditions and the analyzed parameters. The storage condition with $0.4 \mathrm{kPa} \mathrm{O}_{2}+1.2 \mathrm{kPa} \mathrm{CO}_{2}$ presents a good correlation with the flesh firmness and healthy fruit. Flesh firmness was not associated with the ethylene production. Ethylene acts on the expression of enzymes involved with the cell wall degradation, such as polygalacturonase, pectin methylesterase, xyloglucan endotransglucosylase, cellulases, and others (Hiwasa et al. 2003; Prasanna et al. 2007). It was observed that as the oxygen partial pressures decreased (Table 1), ethylene production was reduced, which reflects in higher flesh firmness 
(Fig. 2f). Thewes et al. (2015) have also verified in 'Galaxy' and 'Royal Gala' apples stored under ULO and DCA-CF a higher flesh firmness in comparison to conventional controlled atmosphere (CA). However, when the fruits were stored under $0.25 \mathrm{kPa} \mathrm{O}_{2}+0.0 \mathrm{kPa} \mathrm{CO}_{2}$, in a static form, the flesh firmness was lower. This finding could be related to the damage due to accumulation of anaerobic metabolism compounds. However, when 'Galaxy' and 'Royal Gala' apples were in a DCA storage where the oxygen partial pressure was monitored by the respiratory quotient (DCA-RQ), and possessing an average $\mathrm{O}_{2}$ near to $0.25 \mathrm{kPa}$, flesh firmness maintenance was observed (Thewes et al. 2017; Both et al. 2017).

(a)

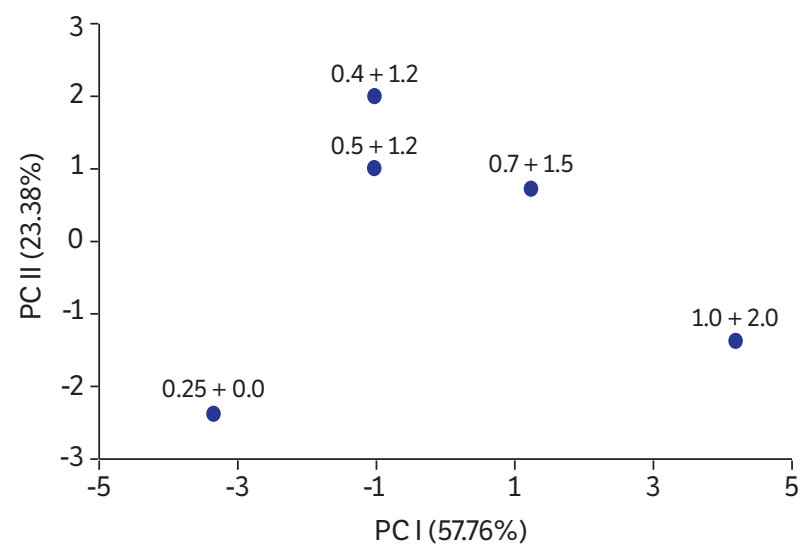

(b)

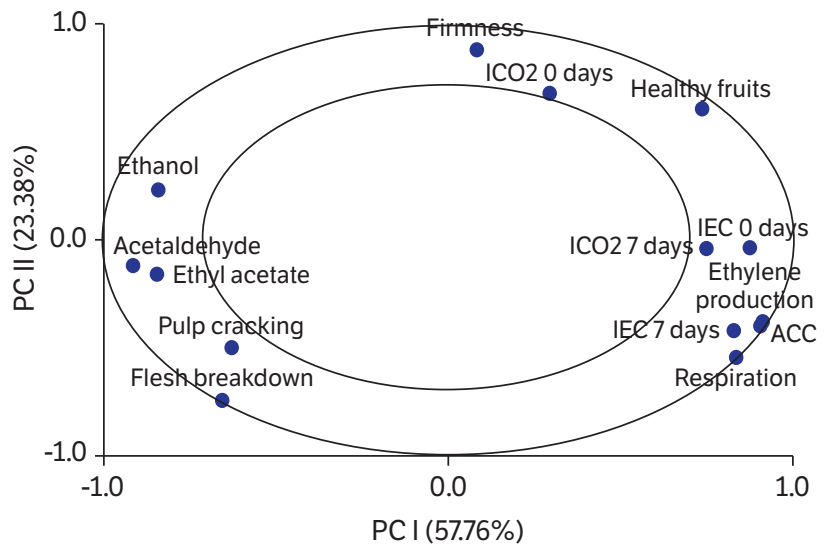

Figure 3. Scores (a) (treatments) and correlation loadings (b) (variables) of 'Royal Gala' apple stored under $1.0 \mathrm{kPaO} \mathrm{O}_{2}+2.0 \mathrm{kPa} \mathrm{CO}, 0.7 \mathrm{kPaO}$ $+1.5 \mathrm{kPa} \mathrm{CO}_{2}, 0.5 \mathrm{kPaO}_{2}+1.2 \mathrm{kPa} \mathrm{CO}_{2}, 0.4 \mathrm{kPaO}_{2}+1.2 \mathrm{kPa} \mathrm{CO}_{2}$ and $0.25 \mathrm{kPaO}_{2}+0.0 \mathrm{kPa} \mathrm{CO}_{2}$ during 9 months plus 7 days of shelf life at $20{ }^{\circ} \mathrm{C}$.

In the PCA, a correlation between flesh breakdown and pulp cracking can also be noticed with the higher concentrations of acetaldehyde and ethyl acetate (anaerobic metabolism products accumulation) in the extremely low oxygen condition of $0.25 \mathrm{kPa} \mathrm{O}_{2}+0.0 \mathrm{kPaCO}$ (Fig. 3a and b). This can be explained by the rapid decrease of oxygen, from an aerobic to anaerobic level, which results in an accumulation of toxic volatile substances and, consequently flesh breakdown, characterized as physiological disorders (Pedreschi et al. 2009) and the pulp cracking. Ceretta et al. (2010) reported that the storage of 'Gala' apple at $\mathrm{O}_{2}$ conditions under $0.8 \mathrm{kPa}$ at $0{ }^{\circ} \mathrm{C}$ can increase the incidence of pulp cracking. In contrast, Weber et al. (2011) verified in 'Royal Gala' apples stored under ULO 0.6 kPa $\mathrm{O}_{2}$ at a temperature of $1{ }^{\circ} \mathrm{C}$ lower occurrence of flesh breakdown. Therefore, it can be affirmed that there is a limit of reduction of the oxygen partial pressure under static $\mathrm{CA}$, especially when the reduction of oxygen is fast at the beginning of the storage period (Fig. $2 \mathrm{~b}$ and $\mathrm{c}$ ), which below this limit, impair the quality of the fruits.

\section{CONCLUSION}

The $0.4 \mathrm{kPa} \mathrm{O}_{2}+1.2 \mathrm{kPa} \mathrm{CO}_{2}$ storage condition was efficient in maintaining the quality of 'Royal Gala' apples stored for 9 months followed by 7 days at $20^{\circ} \mathrm{C}$ allowing lower ethylene production, higher flesh firmness, lower pulp cracking and lower flesh breakdown occurrence.

The storage in the static conditions of $0.25 \mathrm{kPa} \mathrm{O}_{2}+0.0 \mathrm{kPa} \mathrm{CO}_{2}$ did not maintain the quality of the fruits, presenting higher incidence of pulp cracking and flesh breakdown, thus these gas partial pressures are not recommended for storing 'Royal Gala' apple during 9 months in a static CA. 


\section{FUNDING}

Conselho Nacional de Desenvolvimento Científico e Tecnológico

[https://doi.org/10.13039/501100003593]

Grant \# 305737 / 2013-9

\section{AUTHORS' CONTRIBUTION}

Conceptualization, Berghetti M. R. P., Brackmann A., Thewes F. R., Schultz E. E., Ludwig V.; Methodology, Berghetti M. R. P., Wendt L. M.,Thewes F. R. and Schmidt S. F. P.; Investigation, Berghetti M. R. P., Brackmann A., Thewes F. R., Schultz E. E., Ludwig V., and Schmidt S. F. P.; Writing - Original Draft, Berghetti M. R. P., Brackmann A., Thewes F. R.; Writing Review and Editing, . Berghetti M. R. P., Schultz E. E., Ludwig V.,Thewes F. R. and Schmidt S. F. P.; Funding Acquisition, Berghetti M. R. P., Brackmann A., Supervision, Berghetti M. R. P., Schultz E. E., Thewes F. R. and Schmidt S. F. P

\section{REFERENCES}

[AGAPOMI] Associação Gaúcha dos Produtores de Maçã (2018). [Accessed Aug. 27, 2018]. Available at: http://agapomi.com.br/ informacoes/dados-estatisticos/

Asoda, T., Terai, H., Kato, M. and Suzuki, Y. (2009). Effects of postharvest ethanol vapor treatment on ethylene responsiveness in broccoli. Postharvest Biology and Technology, 52, 216-220. https://doi.org/10.1016/j.postharvbio.2008.09.015

Beaulieu, J. C. and Saltveit, M. E. (1997). Inhibition or promotion of tomato fruit ripening by acetaldehyde and is concentration dependent and varies with initial fruit maturity. Journal of American Society of Horticultural Science, 122, 392-398. https://doi.org/10.21273/JASHS.122.3.392

Both, V., Thewes, F. R., Brackmann, A., Anese, R. O., Ferreira, D. F. and Wagner, R. (2017). Effects of dynamic controlled atmosphere by respiratory quotient on some quality parameters and volatile profile of 'Royal Gala' apple after long-term storage. Food Chemistry, 215, 483-492. https://doi.org/10.1016/j.foodchem.2016.08.009

Brackmann, A., Weber, A. and Both, V. (2015). $\mathrm{CO}_{2}$ partial pressure for respiratory quotient and Harvest Watch ${ }^{\mathrm{TM}}$ dynamic controlled atmosphere for 'Galaxy’ apple storage. Acta Horticulturae, 1079, 435-440. https://doi.org/10.17660/ActaHortic.2015.1079.56

Brackmann, A., Anese, R. O., Weber, A., Both, V., Gasperin, A. R. and Pavanello, E. P. (2013). Efeito do estresse inicial por baixo oxigênio combinado com 1-metilciclopropeno na conservação de maçãs 'Royal Gala’ armazenadas com ultrabaixo oxigênio. Ciências Agrárias, 34, 1185-1194. https://doi.org/10.5433/1679-0359.2013v34n3p1185

Brackmann, A., Both, V., Weber, A., Both, V., Pavanello, E. P., Schor, R. M. R. W. and Santos, J. R. A. (2012). Variação da temperatura, oxigênio e $\mathrm{CO}_{2}$ durante o armazenamento em atmosfera controlada de maçãs 'Royal Gala'. Ciência Rural, 42, 1386-1391. https://doi. org/10.1590/S0103-84782005000500010

Brackmann, A., Weber, A., J. A. V., Neuwald, D. A. and Steffens, C. A. (2008). Manutenção da qualidade pós-colheita de maçãs ‘Royal Gala' e ‘Galaxy’ sob armazenamento em atmosfera controlada. Ciência Rural, 38, 2478-2484. https://doi.org/10.1590/S0103-84782008000900010

Bufler, G. (1986). Ethylene-promoted conversion of 1-aminocyclopropane-1-carboxylic acid to ethylene in peel of apple at various stages of fruit development. Plant Physiology, 80, 539-543. https://doi.org/10.1104/pp.80.2.539

Camilo, A. P. and Denardi, F. (2006). Cultivares: Descrição e comportamento no Sul do Brasil. In: EPAGRI. A cultura da macieira. Florianópolis: Empresa de Pesquisa Agropecuária e Extensão Rural de Santa Catarina, cap. 5, 113-168. 
Castro, E., Barrett, D. M., Jobling, J. and Mitcham, E. J. (2008). Biochemical factors associated with a $\mathrm{CO}_{2}$ induced flesh browning disorder of 'Pink Lady' apples. Postharvest Biology and Technology, 48, 182-191. https://doi.org/10.1016/j.postharvbio.2007.09.027

Ceretta, M., Brackmann, A., Pinto, J. A. V., Lúcio, A. D. and Anese, R. O. (2010). Tolerância da maçã ‘Gala’ a pressões parciais extremas de $\mathrm{O}_{2}$ e $\mathrm{CO}_{2}$ durante o armazenamento. Revista Brasileira de Armazenamento, Viçosa, 35, 60-69.

Forney, C. F., Kalt, W. and Jordan. M. A. (2000). The composition of strawberry aroma is influenced by cultivar, maturity and storage. Horticulture Science, 35, 1022-1026. https://doi.org/10.21273/HORTSCI.35.6.1022

Hiwasa, K., Kinugasa, Y., Amano, S., Hashimoto, A., Nakano, R., Inaba, A. and Kubo, Y. (2003). Ethylene is required for both the initiation and progression of softening in pear (Pyrus communis L.) fruit. Journal of Experimental Botany, 54, 771-779. https://doi.org/10.1093/jxb/erg073

Lee, J., Rudell, D. R., Davies, P. J. and Watkins, C. B. (2012). Metabolic changes in 1-methylcyclopropene (1-MCP)-treated 'Empire' apple fruit during storage. Metabolomic, 8, 742-753. https://doi.org/10.1007/s11306-011-0373-5

Lehninger, A. L., Nelson, D. L. and Cox, M. M. (2002). Princípios de bioquímica. 3.ed. São Paulo: Sarvier.

Li, Z., Gemma, H. and Iwahori, S. (2002). Stimulation of 'Fuji' apple skin color by ethephon and phosphorus-calcium mixed compounds in relation to flavonoid synthesis. Scientia Horticulturae, Amsterdam, 94, 193-199. https://doi.org/10.1016/S0304-4238(01)00363-6

Mannapperuma, J. D., Singh, R. P. and Montero, M. E. (1991). Simultaneous gas diffusion and chemical reaction in foods stored in modified atmosphere. Journal of Food Engineering, 14, 167-183. https://doi.org/10.1016/0260-8774(91)90006-E

Nanos, G. D., Romani, R. J. and Kader, A. A. (1992). Metabolic and other responses of 'Bartlett' pear fruit and suspension-cultured 'Passe Crassane' pear fruit cells held in $0.25 \% \mathrm{O}_{2}$. Journal of American Society of Horticultural Science, 117, 934-940.

Pedreschi, R., Franck, C., Lammertyn, J., Erban, A., Kopka, J., Hertog, M., Verlmden, B. and Nicolai, B. (2009). Metabolic Profiling of 'Conference’ pears under low oxygen stress. Postharvest Biology and Technology, 51, 123-130. https://doi.org/10.1016/j.postharvbio.2008.05.019

Pesis, E. (2005). The role of the anaerobic metabolites, acetaldehyde and ethanol, in fruit ripening, enhancement of fruit quality and fruit deterioration. Postharvest Biology and Technology, 37, 1-19. https://doi.org/10.1016/j.postharvbio.2005.03.001

Prasanna, V., Prabha, T. N. and Tharanathan, R. N. (2007). Fruit ripening phenomena - an overview. Critical Reviews in Food Science and Nutrition, 47, 1-19. https://doi.org/10.1080/10408390600976841

Saltveit, M. E. (1999). Effect of ethylene on quality of fresh fruits and vegetables. Postharvest Biology and Technology, 15, 279-292. https:// doi.org/10.1016/S0925-5214(98)00091-X

Saquet, A. A. and Streif, J. (2008). Fermentative metabolism in 'Jonagold' apples under controlled atmosphere storage. European Journal of Horticultural Science, 73, 43-46.

Streif, J. (1984). Jod-Stärke-test zur beurteilung der fruchtreife bei Äpfeln. Obst und Garten. 8, 12.

Taiz, L. and Zeiger, E. (2009). Fisiologia Vegetal, 3.ed. Porto Alegre: Artemed.

Thewes, F. R., Brackmann, A., Anese, R. O., Ludwig, V., Schultz, E. E., Santos, L. F. and Wendt, L. M. (2017). Effect of dynamic controlled atmosphere monitored by respiratory quotient and 1-methylcyclopropene on the metabolism and quality of 'Galaxy' apple harvested at three maturity stages. Food Chemistry, 222, 84-93. https://doi.org/10.1016/j.foodchem.2016.12.009

Thewes, F. R., Both, V., Brackmann, A., Weber, A. and Anese, R. O. (2015). Dynamic controlled atmosphere and ultralow oxygen storage on 'Gala' mutants quality maintenance. Food Chemistry, 188, 62-70. https://doi.org/10.1016/j.foodchem.2015.04.128

Yang, S. F. and Hoffman, N. E. (1984). Ethylene biosynthesis and its regulation in higher plants. Annual Review of Plant Physiology, 35, 155-189. https://doi.org/10.1146/annurev.pp.35.060184.001103 
Wang, K. L., Li, H. and Ecker, J. R. (2002). Ethylene biosynthesis and signaling networks. The Plant Cell, 14, suppl. 1, S131-S151. https:// doi.org/10.1105/tpc.001768

Watkins, C. B. (2006). The use of 1-metylcyclopropene (1-MCP) on fruit and vegetables. Biotechnology Advances, 24, 389-409. https:// doi.org/10.1016/j.biotechadv.2006.01.005

Watkins, C. B. (2008). Dynamic controlled atmosphere storage - a new technology for the New York storage industry. Biotechnology Advances New York Fruit Quarterly, 16, 23-26.

Weber, A., Brackmann, A., Both, V., Pavanello, E. P., Anese, R. O. and Schorr, M. R. W. (2016). Ethanol reduces ripening of 'Royal Gala' apples stores in controlled atmosphere. Anais da Academia Brasileira de Ciência, 88, 403-410. https://doi.org/10.1590/0001-3765201620140181

Weber, A., Brackmann, A., Anese, R. O., Both, V. and Pavanello, E. P. (2013). Atmosfera controlada para o armazenamento da maçã 'Maxi Gala'. Revista Ciência Agronômica, 44, 294-301. https://doi.org/10.1590/S1806-66902013000200011

Weber, A., Brackmann, A., Anese, R. O., Both, V. and Pavanello, E. P. (2011). 'Royal Gala’ apple quality stored under ultralow oxygen concentration and low temperature conditions. Pesquisa Agropecuária Brasileira, 46, 1597-1602. https://doi.org/10.1590/S0100-204X2011001200003

Zabalza, A., van Dongen J. T., Froehlich, A., Oliver, S. N., Faix, B., Gupta, K. J., Schmälzlin, E., Igal, M., Orcaray, L., Royuela, M. and Geigenberger, P. (2009). Regulation of respiration and fermentation to control the plant internal oxygen concentration. Plant Physiology, 149, 1087-1098. https://doi.org/10.1104/pp.108.129288

Zanella, A. (2003). Control of apple superficial scald and ripening - a comparison between 1-methylcyclopropene and diphenylamine postharvest treatments, initial low oxygen stress and ultra-low oxygen storage. Postharvest Biology and Technology, 27, 69-78. https:// doi.org/10.1016/S0925-5214(02)00187-4

Zanella, A., Cazzanelli, P. and Rossi, O. (2008). Dynamic controlled atmosphere (DCA) storage by the means of chlorophyll fluorescence response for firmness retention in apple. Acta Horticulturae, 796, 77-82. https://doi.org/10.17660/ActaHortic.2008.796.7 